AWEJ for Translation \& Literary Studies, Volume 4, Number2. May 2020

DOI: http://dx.doi.org/10.24093/awejtls/vol4no2.16

Pp.221- 232

\title{
Persona in Kazuo Ishiguro's The Remains of the Day
}

\author{
Assil GHARIRI \\ Department of English \\ Faculty of Letters and Foreign languages \\ University of Abou Bekr Belkaid \\ Tlemcen, Algeria
}

\begin{abstract}
This article studies the archetype of the persona in Kazuo Ishiguro's novel, The Remains of the Day (1989). It deals with the journey that the protagonist Mr. Stevens takes through the unconscious in search of his real self, in which his true persona is revealed. The article mentions, also, the archetype of shadow, which is considered, in most cases, inseparable from the persona archetype. In this novel, the shadow helps the reader realize the true self of Mr. Stevens that has been covered for years by his misleading persona. The article clarifies to what extinct the absence of a real self leads to distorted archetypes. The article uses Carl Jung's theory of individuation, concentrating mainly on the idea of archetypes. Thanks to memory, a real sense of self, and thus persona is discovered. The persona, in this article, is discussed as one of the astonishing abilities of the unconscious that enables people to hide a lot about their real selves behind it, reminding the reader, therefore, not to be cheated by the appearances.
\end{abstract}

Keywords: British persona, Carl Jung, Kazuo Ishiguro, self, shadow, The Remains of the Day, unconscious.

Cite as: GHARIRI, A. (2020). Persona in Kazuo Ishiguro's The Remains of the Day. Arab World English Journal for Translation \& Literary Studies 4 (2). 221- 232.

DOI: http://dx.doi.org/10.24093/awejtls/vol4no2.16 
AWEJ for Translation \& Literary Studies Volume, 4 Number 2 May 2020

Persona in Kazuo Ishiguro's The Remains of the Day

\section{Introduction}

\section{The Remains of the Day: A Remarkable Novel}

The Remains of the Day is the third book of Kazuo Ishiguro, for which he won the Booker prize in 1989 (Parkes, 2001). It is a novel told in the first-person narrative and revolves around the life of Mr. Stevens who is both the narrator and the protagonist. Stevens is a butler, who works in Darlington Hall. He used to be the loyal butler of Lord Darlington, but after the death of this latter, An American lord called Mr. Farraday owns the house. Indeed, Stevens cannot get accustomed to Mr. Farraday's manner of talking and joking and he, even, faces many difficulties in interacting with his new master. However, it is Mr. Farraday who suggests to Stevens, one evening, to take a trip around England -- a journey that would change Stevens' whole life.

Actually, Mr. Farraday's suggestion was not, at first, taken seriously by Stevens. It is not until Stevens receives a letter from Miss. Kenton that he starts taking the matter of the trip into consideration. Miss. Kenton is a former housekeeper in Darlington Hall. She worked with Stevens for fifteen years and then got married. After twenty years of marriage, Kenton sends a letter to Stevens who, repeatedly reading the letter, assumes that she alludes to a failed marriage and wants, thus, to come back to Darlington Hall as a housekeeper. Therefore, in July 1956, Stevens starts a six-day journey to visit Miss Kenton. It becomes a journey in which he remembers and recollects all the events, the experiences, and the relationships he had during his service career at Darlington Hall. His relation to Lord Darlington, who turns out to be a Nazi corroborator, and his relation to Miss Kenton are some he remembers.

Steven's romantic attraction to Miss Kenton is never mentioned frankly, but is alluded to on different occasions. In their last meeting, at the end of the novel, Kenton professes to Stevens that she has always dreamt of life joining them together. Indeed, this profession has broken Stevens' heart and changed his whole view of life and his self. The novel ends with Stevens' decision to profit from the remains of his day and to learn to get more intimacy with people in general and with his new master in particular.

Now, this article is concerned with the protagonist of the novel, Mr. Stevens. It analyses his persona during his life career at Darlington Hall and the way he becomes aware of it at the end. Throughout the whole novel, Stevens is rewriting his old self so that it could adopt a new shape. Through remembering and recollecting the events of the past, Stevens will compose a clear picture about his suppressed persona, he will be able to see the mistakes he has committed and he can even admit them once he gets aware of his persona. The article attempts to answer the question: does the absence of a real self affect the personal archetypes?

The article will analyze Stevens' persona, using Carl Jung's method of individuation. It should be noted; however, that the theory of individuation won't be used on its whole, instead the analysis will tackle the idea of archetypes. Through his recollection of past information, Stevens' archetypes become clear. The paper will investigate what creates Stevens' suppressed self and how he will meet it finally.

Arab World English Journal for Translation \& Literary Studies 
AWEJ for Translation \& Literary Studies Volume, 4 Number 2 May 2020

Persona in Kazuo Ishiguro's The Remains of the Day

\section{Literature Review: \\ Jung's Theory:}

Jung's theory of individuation is based on certain concepts that should be defined and understood. The first concept is individuation itself. According to Jung, in order to be mentally sound, people have vigorous access to the different part of their selves. But, unfortunately, most people do not know how to do that and, consequently, they become unaware of the different elements of their psyches. Here, actually, comes the role of the individuation process. Through such process, people should gather all the parts of their true selves. This is could be done by realizing what their dreams and daydream images are telling them and by believing in their uniqueness. "Individuation means becoming a single, homogenous being, and in so far as individuality embraces or innermost, last, and incomparable uniqueness, it also implies becoming one's own self. We could therefore translate individuation as coming to selfhood or selfrealization" (Kellis, 2007, p. 324).

However self should not be perceived as the ego. The ego, for Jung, the ego is "the center of the unconscious, the world of time and space" (Gibson, Lathrop, Stern 1991, p. 65). Differently said it is the conscious part of the mind. Thus, ego is considered as a part of the self and it depends on it.

On the other hand, there is the concept of the unconscious which has been debated by many philosophers and psychologists. Jung's teacher, Freud, defined the unconscious as "the gathering place of forgotten and replaced contents" (Jung, 1972, p. 3).

Jung (1972) argued that the unconscious could be both personal and collective. The personal unconscious contains "autonomous complexes" and "disturbing factors that disrupt conscious control and act like true disturbers of peace" (p.230). Thus, the personal unconscious includes the different suppressed believes and memories that belong to a certain individual regarding his own experience.

The collective unconscious, on the other hand, "is not individual but universal-- it has contents and modes of behavior that are more or less the same everywhere and in all individuals" (Jung , 1972, p. 4). Hence, the collective unconscious is shared by all the people around the world and it originates from the experiences of the ancestors. So, when dealing with certain notions of the external world, the ancestors developed given experiences and images that are reflected in people's myths, legends, folktales...etc. Those images, indeed, do not have contents, however, through practice and with time, they developed contents and they become known as archetypes

The archetypes are original images related to all universal themes familiar to all people. Their place is in the unconscious and they date back to distant times. The frames of the archetypes are universal but their tenors are personal. In his book, A Study Guide for Psychologists and Their Theories for Students: Carl Jung, Gale Cengage Learning (2017) claims that: “in Jung's words, archetypes are by definition, factors and motifs that arrange the psychic elements into certain images" (p.26). Jung (2017), also, adds that "toward the end of his life, Jung strengthened the 
connection between emotions and archetypes by redefining the archetypes as innate releasing mechanisms linked to universal human emotions" (p.26).

Among the most important archetypes is the persona. The persona is considered sometimes as the first archetype, "is that which in reality one is not, but which one self as well as others think one is" (Jung, 1981, p.123). Put differently, it is the mask that each of us wears to behave properly in society and to control his/her different relationships. The persona is not individual, although it seems so. It is an identity imposed on us by the society. In other words, it is an ideal image we create to please the society. Indeed, each persona has certain features and characteristics related to it depending on one's role in society. Thus, each individual creates his/her persona basing on what his society expects him/her to be.

Nonetheless, sticking too much to persona can be harmful. People need to know when to give up their persona for their real identities. As a matter of fact, most people tend to stick to their persona, because the society rewards the people for what they show and not for what they really are. That's why most people tend to bury their selves deeply to the extent that they forget, totally, about them.

Indeed, letting go of the persona could be really scary, for it has remarkable consequences. People may feel really vulnerable exposing their selves, openly. They may lose certain ranks, they sought for, long, in society or will face constant complain about how they unexpectedly changed. Thus, having a certain persona that you can take apart in given situations is a hard task for a lot of people:

"Carl Jung calls the individual who identifies himself with his persona a mana personality...that's a person who is nothing but the role he or she plays. A person of this sort never lets his actual character develop. He remains simply a mask and his powers fail" (Mcdonald 2014, pp. 135-136).

Although the persona, always, seeks the perfection, it is, most of the time, faced and hampered by the shadow archetype. The shadow, the second archetype, is "described as composed of the dark elements of the personality" (Rothgeb, 1994, p. 59). It is somehow similar to Freud's Id. The shadow contains the negative ideas and believes that the person feels ashamed to bring to conscious. However, bringing them to conscious is, for Jung, the first step to get healed.

As opposed to the persona which wants to be ideal and to match what is expected from it in the society, the shadow, simply does not want so. The shadow wants the person to confront his/her reality and to adopt it. Hence, the more the people realize the contents of their shadow, the less psychologically frustrated they feel. But, admitting the dark side of our selves is neither easy nor cozy. It is a side that most people feel reluctant to confront; instead, they find it safer to project it on others. In fact, most, if not all, the contents of the shadow are repudiated by the society, especially, if it is an obstructive and prohibitive one where the shadow could dominate the large part of the unconscious.

Arab World English Journal for Translation \& Literary Studies 
Regardless of people's admission of their shadow, it is still projected in their selves, deeds or thoughts. That's why the frequent answer to the question 'why did you do that?' addressed to a person who has done a mistake liking stealing, lying, hurting others...etc is 'I don't know' or 'it is like it was not me'. That's partially, true because people, mostly, are not aware of when or how their shadow is going to show up. Actually, the shadow is inevitable. Simply, all the human beings have a shadow, "everyone carries a shadow, and the less it is embodied in the individual conscious life, the blacker and the denser it is" (Freed 56).

The events of The Remains of the Day go back to July 1956.In his article "Trauma, Memory and History in Kazuo Ishiguro's Fiction," Guo (2012) mentions that 1956 is the same year where "Margret Thatcher's conservative government aimed to emulate the Victorians" (p. 2512). Moreover, Thatcher explained in the election campaign her wish to "reglorify Britain" and it is glorification that Mr. Stevens tries to achieve in this novel. He, actually, devotes his life to achieve dignity, glory and greatness. Indeed, the characteristics of Mr. Stevens' personality could be projected on the British Empire which through history had strived to be the great and the glorified empire ever:

I would say that it is the very lack of obvious drama or spectacle that sets the beauty of our land apart. What is pertinent is the calmness of that beauty, its sense of restraint. It is as though the lad knows of its own beauty, of its own greatness and feels no need to shout it. In comparison, the sort of sight offered in such places as Africa or America, though undoubtedly very exciting, strike the objective viewer as inferior on account of their unseemly demonstrativeness (Ishiguro, 1988, p.29).

The novel starts with Mr. Stevens taking a journey to the place where Miss. Kenton, the former housekeeper, has been living since getting married. His decision to walk a step far from Darlington's Hall is after he receives a letter from Miss. Kenton alluding that she has problems with her husband and she may want to come back to Darlington's Hall, or this what Mr. Stevens wants to understand.

\section{Data Analysis and interpretation Stevens' Persona}

Actually, throughout his life, Stevens has been the prisoner of Darlington hall and of his own Persona archetype. For him: "the great butlers are great by virtue of their ability to inhabit their professional role and inhabit it to the utmost" (Ishiguro, 1989, pp. 42-43). Stevens spends his life wearing the mask of greatness and to maintain the role of a great butler, he suppresses all his beliefs and feelings. He believes that being an English butler is the pure portray of greatness. Eventually, by agreeing on taking a journey throughout England, Stevens is, also, wandering through his unconscious and trying to prove that what he has spent his life doing is worthwhile. Thus, the road he takes to reach Miss Kenton is a road to his unconscious too.

Once Stevens starts his voyage, his memory begins to bring back to him all the events he has passed through, within the walls of Darlington Hall. As opposed to Augustine, who starts 
his Confessions with the 'origins stage' in which he remembers the events of his childhood and adolescence, Stevens begins directly recollecting his adulthood's events as if nothing happens in his childhood and adolescence stages that is worth of remembering. The reader feels, as though, Stevens is destined to be a butler, so, what matters is when being as such, another period would be of no importance.

When first mentioning the trip, Mr. Stevens uses the word "imagination", a term which reflects the fact that Mr. Stevens had never gone outside, to the extent that if he would think about anything which lies outside Darlington Hall, then his ideas would be purely imaginative. Nevertheless, Stevens Believes that he knows everything about England and impliedly about his self, he states "it has been my priviliege to see the best of England over the years, sir, within these very walls" (Ishiguro, 1989, p. 4).

In fact, through the years of serving in Darlington Hall, Stevens develops a very strict persona. For him, everything has rules that must be respected. He is accustomed to put strict "margins" for the staff who work under his command and for everything that can or must be done inside Darlington Hall. However, by doing so, Stevens has been putting strict margins for his persona, as well. Mr. Stevens is a purely professional butler who has never thought of anything else rather than the complete mastering of his work. Thus, the idea of getting outside Darlington Hall has not hit his mind ever. It is, in fact, Lord Farraday, the American new owner of Darlington Hall, who suggests to Stevens the idea of taking a journey around England You realize, Stevens, I don't expect you to be locked up here in this house all the time I'm away. Why don't you take the car and drive off somewhere for a few days" (Ishiguro, 1989, p. 3)?

Mr. Farraday is, therefore, the first person who suggest to Steven to take the first steps out of his suppressed self. However, this offer is not taken seriously by Stevens. He considers it as "instance of an American gentleman's unfamiliarity with what was and what was not commonly done in England" (Ishiguro, 1989, p4). For Stevens, such an offer is the "most kind suggestion" never thought of (Ishiguro, 1989, p.3). It is not, actually, until he receives a letter from Miss. Kenton, the former housekeeper, that Stevens took Lord. Farraday's suggestion into consideration. However, he makes sure to hide and change any idea that may sneak to the reader's head that he is going to take the trip only for the sake of meeting Miss. Kenton:

I found myself reconsidering Mr Farraday's kind suggestion of some days ago. For it had occurred to me that the proposed trip in the car could be put to good professional use; that is to say, I could drive to the West Country and call on Miss. Kenton in passing, thus exploring at first hand the substance of her wish to return to employment here at Darlington Hall. (Ishiguro, 1989, p.10)

Actually, Mr. Stevens believes that he knows his real self and is proud of it. He claims that under his command, very few mistakes and errors happened that are not, indeed, worth talking of: 
The fact is, over the past few months, I have been responsible for a series of small errors in the carrying out of my duties. I should say that these errors have all been without exception quite trivial in themselves. Nevertheless, I think you will understand that to one not accustomed to committing such errors, this development was rather disturbing, and I did in fact begin to entertain all sorts of alarmist theories as to their cause. (Ishiguro, 1989, p.5)

But, to expose such a self to experience would be something terrifying and Mr. Stevens is not keen of finding out things about his persona that he would rather remain blind of.

Indeed, when Stevens decides to take the trip after receiving a letter from Miss. Kenton, the former housekeeper, he starts to consider each tiny detail to prepare himself for his journey. $\mathrm{He}$, for instance, afraid, that "the staff plan would, furthermore, for each of the four resident employees mean a radical altering of respective customary duties" or that the employees will have "an unhealthy amount of time on their hands" (Ishiguro, 1989, p.8). However, the thing that really preoccupied Stevens' mind is the manner of clothing: "Then there was the question of what sorts of costume were appropriate on such a journey, and whether or not it was worth my while to invest in a new set of clothes" (Ishiguro, 1989, p.10). It seems that Stevens wants to cover something. He is very interested in wearing the appropriate mask that will cover any inappropriate thought or feeling. According to Marshall Berman, "clothes become an emblem of the old, illusory mode of life; nakedness comes to signify the newly discovered and experienced truth" (Ishiguro, 1989, p.106). Therefore, Stevens aims to hide his real identity through clothing. Throughout the novel, he has often being mistaken for an aristocrat because of his suit. He hides his real self with all its beliefs and emotions under an elegant suit.

Actually, being perplexed by what to wear and thinking that many of his suits are "too formal for the purposes of the proposed trip, or else rather old fashioned these days," Stevens reveals one of his main principles in life: to care, deeply, about the public view and to try to satisfy others rather than himself (Ishiguro, 1989, p.10). He is very afraid of been seen driving the car with the inappropriate suit. But once again, Stevens makes sure of wearing his mask in front of the reader thus the latter cannot feel that Steven is at all emotional about the journey:

I hope you do not think me unduly vain with regard to this latter matter; it is just that one never knows when one might be obliged to give out that one is from Darlington Hall, and it is important that one be attired at such times in a manner worthy of one's position (Ishiguro, 1989, p.11).

Indeed, hiding is not the only reason for Stevens to wear nice suits; he also wants to look great. Greatness is a crucial principle that Stevens' persona is based on. He believes that through serving a great man who has his own political position in England, Stevens would, necessarily, be a great butler and, accordingly, a great Living in a country like England gives another reason for Stevens to be great It is, effectively, a land called "Great Britain" by those who believes in the greatness of 
its beauty (Ishiguro, 1989, p.9). As he stands in front of one of the natural views in his way to Weymouth, where Miss. Kenton lives, Stevens comments on the greatness of his land stating that:

I distinctly felt that rare, yet unmistakable feeling-the feeling that one is in the presence of greatness. We call this land of ours Great Britain, and there may be those who believe this a somewhat immodest practic. Yet I would venture that the landscape of our country alone would justify the use of this lofty adjective (Ishiguro, 1989, p.29).

Dignity, on the other hand, is a highly important feature Stevens believes all butlers must have. For him, dignity "has to do crucially with a butler's ability not to abandon the professional being he inhabits. Lesser butlers will abandon their professional being for the private one at the least provocation (Ishiguro, 1989, p.43). In fact, dignity and greatness are very related virtues, so that the presence of one necessitates the presence of the other :

While I would not retract anything I have previously stated regarding the quality of dignity, I must admit there is something to the argument that whatever the degree to which a butler has attained such quality, if has failed to find an appropriate outlet for his accomplishment he can hardly expect his fellows to consider him great (Ishiguro, 1989, p.122-123).

Indeed, Stevens has the habit of discussing the word dignity and the aspects of the dignified butler with his fellow butlers. He even considers some butlers like Mr. Marshall or Mr. Lane as "competent" for having a dignity. Apparently, Stevens believes that "dignity is something one can meaningfully strive for throughout one's career" (Ishiguro, 1989, p.33). And for that, professionalism is deeply related to dignity. The dignified butlers are those who can abandon their private lives for the professional ones. Thus, professionalism is the standard that Stevens uses to measure the dignity of his colleagues, as well as, his own lord and father, but behind his great and dignified mask, the true identity of Stevens lies.

Throughout his journey, Mr. Stevens meets a number of people who mistakenly took him of a gentleman because of the elegant suits he wears, as well as, the luxurious car he is driving. One of men he met in the street told him "Now I got it. Couldn't make you out for a while, see,' cause you talk almost like a gentleman. And what with you driving an old beauty like this" (Ishiguro, 1989, p. 125). Yet, deeply inside, Stevens approves his inappropriateness in being compared with the true gentleman, therefore, in one of the meeting held in Darlington Hall with the presence of certain important political and economic figures, Stevens decides to minimize his presence in the meeting room through standing in the shadow, so as not to be noticed by any of the visitors (Ishiguro, 1989, p.75).

\section{Stevens' Shadow}

All the beliefs, thoughts and feelings that he feels ashamed or afraid of, are stored in his shadow archetype, although he makes sure that with each move and each word he perfectly suppresses them. In his article, "Sentiment and History in the Remains of the Day" Harting (2011) claims "that the Remains of the Day works to produce a surfeit of feeling or affect on the part of 
the reader, and it does so at the same time that it thematizes emotional distance, repression of desire, and stultifying anti-sentimentalism" (p.3). So, regardless of Stevens' infinite attempts not to appear emotional, his speech according to Harting is highly emotional. It is loaded with words like "beguiling, profound, heart-rending, ineffably sad, deeply moving, and tragedy" (p.2).

In an attempt to hide his desire to change, Stevens claims that his tendency towards learning bantering is not to change anything about his persona of which he is totally proud, but a trial to learn a certain sort of talking that is so cherished by his new American master. He alludes to that saying: "Now actually, like many of us, I have a reluctance to change too much of the old ways. But there is no virtue at all in clinging as some do to tradition merely for its own sake. In this age of electricity and modern heating systems, there is no need at all to employ the sorts of numbers necessary even a generation ago" (pp. 7-8).

Nevertheless, Stevens' persona which seems so wise in some situations appears to be really naïve in others. Mr. Stevens presumes that he is sure of Miss. Kenton's desire to return to Darlington Hall for employment, even though, there is nothing in her letter which openly ensures that, yet the hints that are scattered here and there in her letter, he believes are a vivid proof of that:

at this very moment, no doubt, she is pondering with regret decisions made in the far-off past that have now left her, deep in middle age, so alone and desolate. And it is easy to see how in such a frame of mind, the thought of returning to Darlington Hall would be a great comfort to her. Admittedly, she does not at any point in her letter state explicitly her desire to return; but that is the unmistakable message conveyed by the general nuance of many of the passages. (Ishiguro, 1989, p. 50)

However, when Stevens is preparing himself for the trip and thus checking in an Encyclopedia the places he will pass by, he seems so naïve to think that the German bombs did not, in any way, alter the English countryside.

Practically, the day that Mr. Stevens, the father, died is an unquestionable example of Stevens' power of suppressing. Indeed, Stevens makes sure not to think about his father's deteriorating health by getting busier with the members of the conference which takes place in Darlington Hall. He even avoids checking his father letting this job to Miss. Kenton. The only time that he has the chance to see his father, he does not allow to be driven to any emotional conversation with him. Stevens tries so hard to hold his tears so when he was thought of being crying by Lord Darlington, he uses the pretext of being so tired.

Days before his death, Stevens' father was told by his own son that his duties would be minimized to one required, usually, by new servants. These orders came as a result of an 'embarrassing' incident that took place a week or so earlier. Mr. Stevens senior who was used to serve the visitors of Darlington Hall, was about to serve a tray of refreshments to two guests of Lord Darlington in the summerhouse which is situated in the lawn, as he fell, "scattering the load on his tray-teapot, cups, saucers, sandwiches, cakes- across the area of grass at the top of the steps" 
AWEJ for Translation \& Literary Studies Volume, 4 Number 2 May 2020

Persona in Kazuo Ishiguro's The Remains of the Day

(Ishiguro, 1989, p.66). An incident that caused a lot of embarrassment to Mr. Stevens and his father who kept repeating that it was not his fault but this of the steps.

Mr. Stevens Senior could not bear the shame of committing a mistake that, for him, would erase a whole career of commitment and bestowal. Mr. Stevens, the father kept returning to the place where he fell, walking back and forth on the steps to find out the reason that made him fall attempting, as though, to convince himself along with those surrounding him that his value as a butler and, thus, as a man. Watching him, along with Miss. Kenton, Stevens stated: "I can describe his manner at that moment no better than the way Miss. Kenton puts it in her letter; it was indeed 'as though he hoped to find some precious jewel he had dropped there" (Ishiguro, 1989, p.70).

Such jewel is his greatness that was taken out from him the day he was told that he can no more be one of the principle butlers in Darlington Hall. Therefore, days after this incident, Mr. Stevens that father's health deteriorated and he soon had a stroke and passed away. Mr. Stevens' attitude towards Lord Darlington is another contradictory matter. Lord Darlington is believed, by the British people, to be a Nazi ally who sympathizes with Germany, either during World War I or after it. He is one of the important figures who stand against any punishment of Germany following the crimes it committed during the war. However, ironically, Stevens has never doubted his master' actions nor has he noticed such vices that every person in Britain now accuses Lord Darlington to have,

and when today one hears talk about his lordship, when one hears the sort of foolish speculations concerning his motives as one does all too frequently these days, I am pleased to recall the memory of that moment as he spoke those heartfelt words in the near-empty banqueting hall. Whatever complications arose in his lordship's course over subsequent years, I for one will never doubt that a desire to see 'justice in this world' lay at the heart of all his actions. (Ishiguro, 1989, p.76)

Actually, Lord Darlington expresses in many occasions his sympathy towards Germany; he keeps moving from country to country and continually receiving guests in his Hall, only to convince them about the cruelty of applying the treaty of Versailles against Germany. Listening to all his speeches, Stevens cannot but naively admire and be moved by his eloquent style rather than thinking deeply about his attitude; "of course, I had heard these same sentiment expressed by his lordship in many occasions before...I could not help but be moved afresh" (Ishiguro, 1989, p.96).

In spite of mentioning, previously, that Lord Darlington is anti-Semitic, Stevens cannot completely hide that he is touched by the dismissal of two Jewish girls from Darlington Hall. Lord Darlington who stopped any donation to any local charity whose management committee is probably Jewish, justifies that with the fact that his guests' safety is the priority. Therefore, under the order of Lord Darlington himself and despite the fact that, the Jewish girls do no harm to Lord Darlington and the fact that Miss. Kenton is totally against this decision, Stevens dismisses the girls claiming that "I don't have to remind you that our professional duty is not to our foibles and sentiments, but to the wishes to our employer" (Ishiguro, 1989, p.157). However, when Lord

Arab World English Journal for Translation \& Literary Studies 
Darlington admits that what he did was wrong and orders Stevens to bring the girls back, this latter states that: "now really, Miss. Kenton, that is quite incorrupt and unfair. The whole matter caused me great concern, great concern indeed. It is hardly the sort of thing I like to see happen in this house" (Ishiguro, 1989, p.161). This declaration pushes Miss. Kenton to say nervously "why, Mr. Stevens, why, why, why, do you always have to pretend?" (Ishiguro, 1989, p.162). Well, Stevens has to pretend to remain great and dignified for himself at least. His duty is not to question his Lord's orders but to follow them.

Ironically, Mr. Stevens who claims to be concerned with his master's moral status contradicts this principal by being blindly loyal to a Nazi ally "where our elders might have been concerned with whether or not an employer was titled, or otherwise from one of the 'old' families, we tended to concern ourselves much more with the moral status of an employer" (Ishiguro, 1989, p.120). But, such moral status is not, for Stevens, about the private beliefs or the principles of the employers, rather it is about serving and working for men who are "furthering the progress of humanity" and doing so Stevens believes that he helps shaping history, "the satisfaction of being able of being able to say with some reason that one's efforts, in however modest a way, comprise a contribution to the course of history" (Ishiguro, 1989, p.121).

\section{Conclusion}

In fact, at the end of the novel, the readers stand perplexed. It is true that they realize that it is a novel about self-deception in which the protagonist rewrites his whole self through remembering and recollecting his memories. However, they can't determine whether they are in front of a tragic or a happy ending or a mixture of both. But, what all the readers are sure of is that Stevens would never be able to know the truth about his real suppressed self, that was covered by his persona, if he did not take a journey through his unconscious and, more precisely through his memory.

It is the act of recollecting that obliges Stevens, at last, to admit that his self is neither great nor dignified, instead, he has, during his whole life, been the prisoner of a suppressed self consuming others' thoughts and beliefs. It is, evidently, the presence of memory that enables Stevens to be aware of his real self. If Stevens forgot his memories and were no more able to remember for one reason or another, and hence not being able to see his persona for what it is, he would never be able to know the truth about his self or even further, he would never have any sense of self.

\section{About the Author:}

Assil GHARIRI, she graduated from the University of Bechar in 2010. After being the valedictorian during my BA studies, she gained a scholarship to Jordan where she obtained a Magister degree in Literature and Criticism from Yarmouk University, in 2013. She is an assistant lecturer at Tahri Mohamed University, Bechar, Algeria.

ORCid ID is: https://orcid.org/0000-0002-8178-8877

Arab World English Journal for Translation \& Literary Studies 


\section{References}

Gibson, K., Lathrop, D., Stern, E, M. (Eds.). (1991). Carl Jung and Soul Psychology. Routledge. Guo, D.(2 012). Trauma, Memory and History in Kazuo Ishiguro's Fiction. Theory and Practice in Language Studies 2 (12), 2508-2516.

Harting, H. (2011). Sentiment and History in The Remains of The day. Otherness: Essays and Studies 2 (1).

Ishiguro, K.(1989). The Remains of The Day. Faber and Faber Ltd.

Jung, C.G. (1972). Two Essays on Analytical Psychology ( G. Adler \& R. F.C. Hull, Trans.) (2 ed.). Princeton University Press.

Jung, C. G. (1959). The Archetypes and The Collective Unconscious. (R.F.C. Hull, Trans.). New Post-traumatic stress disorder: Basic Science and Clinical Practise. Princeton University Press.

Kellis, T. (2007). Equality: the Quest for the Happy Marriage. Gilgamesh Publishing

Learning, G, C. (2017). A Study Guide for Psychologists and Their Theories for Students: Carl Jung. Gale, Study Guides.

MacDonald, G. (2014). Rebuilding your Broken World. Thomas Nelson Publishers.

Parkes, A. (2001). Kazuo Ishiguro's the Remains of the Day: A Reader's Guide. Continuum International Publishing Group Ltd.

Rothgeb, C.L. (Ed.). (1994). Abstracts of the Collected Works of C.G. Jung. London, U.K.: H. Karnac Books. 